\section{Gunfire echoes in debates on public understanding}

While US campuses, academic journals and newspapers remain the main theatres of action in the 'Science Wars', Britain has had its own 'science skirmish', with scientists and sociologists at loggerheads over the question of public involvement in science policy.

The two conflicts, while not identical, share many characteristics - and involve some of the same actors. Those who dismiss claims that scientific knowledge is essentially a social construct also tend to feel that setting priorities for research is essentially a task that should be left to scientific 'experts'.

In contrast, a broader view of science that challenges some of its claims to possess a unique insight into rational thought finds some of its strongest supporters among those who also argue that the public should contribute to the decision-making process.

The focus of the British debate has been on what is generically described as the public understanding of science' (broadly equivalent to the US concept of 'scientific literacy'). In 1985, the Royal Society published what some consider to be a seminal report exhorting scientists to communicate their work more often, with more enthusiam, and more effectively to the public.

\section{High profile science}

The report led to the setting up of a committee on the public understanding of science (COPUS). And the following decade has seen a plethora of related activities, with more science reports in the media, courses in how to communicate science more effectively, and a national science week.

For some, such as Sir Walter Bodmer, principal of Hertford College, University of Oxford, and the author of the Royal Society study, such achievements represent a triumph that is too often underrated. The past decade, he believes, is an example of how "Britain leads the world", not only in science itself, but also in improving its public understanding.

But others, such as Brian Wynne, director of the Centre for the Study of Environmental Change at the University of Lancaster, are more circumspect. Wynne questions the extent to which more public exposure for science will contribute to an issue he believes to be equally important: fostering public trust in science, at a time when issues such as ' $\mathrm{mad}$ cow disease' appear to have dented the public's confidence in science.

Wynne believes that not only does the public have a right to know about publiclyfunded science, but that they also have a right to influence decisions about science.

Such a notion is controversial. There is arguably no more hostile an opponent to

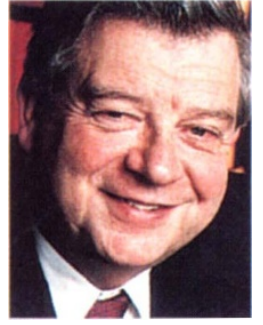

Bodmer: public mus not control science. increased public participation than Lewis Wolpert, professor of biology as applied to medicine at University College London, the present chairman of COPUS, and a sharp critic of the views of sociologists of science. Wolpert says he is all in favour of improving public access to science. He says he is keen to encourage an understanding of the process as well as the history of science, and to involve the public in debates about the implications of science. But, he says, the shaping of science policy should be left to the "experts". He emphasizes, however, that this is his personal view and not necessarily that of COPUS.

"Science policy is a very technical issue," says Wolpert. One or two lay people sitting on advisory committees "will do no harm". But, he adds, "you can't have the public deciding whether to spend money on particle physics or astronomy. They're simply not qualified to make those sorts of decisions. Frankly, I don't think that the public cares."

Wolpert's views are shared to an extent by Bodmer, who says he is in favour of public involvement in science, "but not as a route to controlling scientific, particularly basic, research". Bodmer says it is a contradiction to involve the public in setting priorities for basic research, which is by definition openended and curiosity driven.

But Bodmer, who recently retired as director-general of the Imperial Cancer Research Fund, does not doubt the need for public involvement in issues such as medical and defence research, where the science has clearer implications for public policy. "My whole job at ICRF was to get the public to support us; otherwise there would have been no cancer research," he says.

Such views are widely held. Angela Wilkinson, head of public understanding of science at the Shell oil company, believes that the public care little about the detail of sci- ence policy, but are primarily concerned that they should be able to trust any scientific information they are provided with.

The Brent Spar issue, in which public pressure led Shell to abandon its plans to sink the oil storage facility in the Atlantic, was "basically about people telling the government they did not like the idea of decisions being stitched up between industry and government behind closed doors," says Wilkinson. "This has never been the case. But we decided that if the government was not going to open up, we certainly would." Shell has since opened up decision-making about the future of the Spar to extensive public consultation.

\section{Role for the public}

Signs are, however, beginning to emerge of a change in thinking on the composition of advisory committees, in particular to dispel the idea that public involvement amounts to tokenism. Philip James, director of the Rowett Research Institute in Aberdeen, and author of a report commissioned by the Labour party on the setting up of a food standards agency, has gone as far as recommending that public and consumer interests should dominate the commission that manages the agency. In addition, James has suggested that advisory committees attached to the agency should meet in public.

If taken on board, the James recommendations are expected to open up another issue that some believe strikes at the core of the debate on public involvement in science policy. That question relates to defining the groups or type of people that would qualify for the title 'public'. In other words, should the word be applied to informed but disinterested members of the community at large, to members of advocacy organizations, or simply to individuals chosen at random, who may have very little knowledge of the issues?

Julie Shepherd, senior public affairs officer at the Consumers' Association, is convinced that public representatives need to be fully informed about issues they are asked to deal with. "There is this idea that the 'public' member of an advisory committee should be some Joe Bloggs, or a well turned-out lady from the shires," she says. "But we need consumer advocates who are equipped to challenge and take part in debate." EhsanMasood 